\title{
THE FEATHER-TRACTS OF NORTH AMERICAN GROUSE AND QUAIL.
}

\author{
By Hubert Lyman Clark, Ph. D., \\ Instructor in Zoology, Amherst College.
}

Some years ago the examination of some of our Eastern game birds aroused my interest in the pterylography of the Gallinæ, and I determined to study the pteryloses of as many of the birds of that group as could be procured, my hope being to examine specimens of every North American species. Accordingly, in the autumn of 1892 , a systematic effort to obtain the desired material in the form of fresh or alcoholic birds was begun. It seemed best not to use skins under any cireumstances for the main features of the pterylosis, on account of the distortion unavoidable in their preparation. Owing to the rarity of some species and the difficulty of obtaining others, it proved impossible to carry out the original plan, and the examination of all the North American genera has been substituted for it. That a certain measure of success has been possible, is due to the great courtesy and kindness which has been shown by those to whom application for assistance in procuring birds was made. Every person to whom I have written for birds has gone to no little trouble to accommodate me, and in some cases my indebtedness to these friends is greater than can be repaid, and this is the more remarkable, since in nearly every instance my correspondent and I were complete strangers to each other. Under each genus I have credited the material to the persons from whom it was received, and to all of them $I$ herewith extend my hearty thanks. But there are a few to whom I am under peculiar obligations, and to them more especial thanks are due. To Dr. Mortimer Jesurun, of Douglas, Wyoming, I owe not only some of my best material but the most unusual courtesy in details connected with collecting and shipping the birds; to Mr. Frederic A. Lucas and Dr. R. W. Shufeldt, of Washington, I am indebted for important suggestions; to Mr. R. Ridgway and Dr. C. W. Richmond, of the United States National Museum, for many favors connected with the collections of North American Gallinæ; to Dr. J. A. Allen, of New York City, for assistance in synonymy and identification; to Mr. G. W. Mackay, of Boston, Massachusetts, for his efforts to pro-

Proceedings U. S. National Museum, Vol. XXI-No. 1166.

Proc. N. M. vol. $\mathrm{xxi}-41$ 
cure me specimens of Tympanuchus cupido; and to Mr. Thomas J. Egan, of Halifax, Nova Scotia, for some interesting notes on ptarmigans and a great deal of useful material. Thanks to the exceptional opportunities thus afforded me, I have had the privilege of examining in the flesh 65 specimens, representing 18 species and all the North American genera. The species I have failed to secure are Colinus ridgwayi, Lagopus leucurus, Tympanuchus cupido, and Tympanuchus pallidicinctus. The result of the study of this material has not been in any way extraordinary, but I believe it throws some light on the relationship of the genera, and as the knowledge of pterylography becomes more complete, the facts herein recorded may prove of real value in the classification of the group.

So far as I can ascertain, the only observations which have ever been recorded on the pterylography of the North American Gallinæ are contained in the "System der Pterylographie" of Nitzsch; these relate to only five species and will be considered when I take up the genera to which they belong. So far as the general pterylosis of the group goes, his figures and descriptions do very well, but they are hardly detailed enough to answer the purposes of modern comparative work, while a few of his observations are probably mistakes due to using dried skins as the basis of his work. His preliminary observations on the uniformity of the Gallinine type of pterylosis are only true, as we shall see, of the Alecteropodes, and even among them the Phasianidæ show no little diversity.

The pterylography of our Gallinæ is, however, remarkably uniform, and the generic differences in the fundamental plan are, as a rule, of slight importance. The whole head is uniformly feathered, except for apteria near the eyes and ears. The upper cervical tract is of medium width, but the feathers become larger and fewer as we pass backward, until between the shoulders this tendency reaches its maximum, and here the tract may become more or less forked and often slightly separated from the dorsal tract. The latter is broadest just at the end of the shoulder blades, and from there gradually narrows to the oil gland. The degree of union between the anterior end of the dorsal and the posterior end of the upper cervical tract varies in all the genera and even to a slight extent in individuals. The humeral tracts are always strong and broad, and the parapterum is usually well defined. The femoral tracts are also large and clearly defined, and are one of the most characteristic features of the pterylosis. The feathering of the feet varies markedly in the different genera. The lower cervical tract is usually rather narrow and forks at a variable distance above the furcula. The sternal tracts are very strong and well defined, and are usually connected with the hypoptera by hook-shaped tracts on the sides. The ventral tract is united at the anus, but at a variable distance in front of that point is forked and runs up the breast on either side of the keel of the sternum and may even be more or less united anteriorly with the sternal tracts. Behind the anus is a pteryla formed by the 
under coverts, which may be called the post-anal tract. In addition to these major pterylæ there are often minor ones, such as those formed by the crests on the head or the ruffs on the neck. Aftershafts are always present, and are usually large and downy. True down feathers occur sometimes on the neck and wings, while half-down occurs everywhere bordering on the tracts, especially on the fore part of the breast and on the back between the shoulders. Filoplumes are generally long and numerous among the contour feathers. The oil gland is always tufted. The rectrices, of which the middle pair are always longest, the outer ones shortest, vary in number from 12 to 22 , but the latter number is very unusual. The wing, always quineubital, is very fully feathered, especially on the upper surface, but there is a large apterium along the humerus near its base, in front of the parapterum. There are usually three rows of major superior secondary coverts and two or three of inferior, while the primary coverts are usually in two rows on both surfaces. The primaries are always 10 in number, the secondaries vary between 13 and 21 , and the alula contains 4 or 5 feathers.

One of the most remarkable things about the pterylography of the group is the indifferent specialization of the remiges and, in some species, of the rectrices also. In most birds it is as easy to determine precisely the number of secondaries as of primaries, or perhaps easier; but in the Gallinæ it is not a simple matter to decide where the secondaries end and the coverts begin (on the elbow), so complete is the intergradation. In Lagopus, moreover, the middle tail feathers are so strikingly like coverts that one can hardly feel perfectly sure that they are rectrices. The reverse is true to a somewhat less extent in Centrocercus, where the middle pair of coverts are much like rectrices. Nitzsch speaks of the eleventh remex as always being very small, but I did not find it notably so in most of our American species.

The above observations will not apply, except in a few particulars, to Ortalis, which, as has already been said, differs considerably from the Gallinine type. Having considered the general characters of that type of pterylosis, we will now pass on to a survey of the genera in detail, beginning with the quails.

\section{ODONTOPHORIN Æ.}

The quails form a very natural subdivision of the Gallinæ, characterized by several pterylographical features of more or less importance. The dorsal tract is apparently continuous with the upper cervical tract, and as the latter does not seem to be forked there is no dorsal apterium. The lower cervical tract forks very far up on the throat, and on the side there seems to be scarcely a trace of the hook connecting the sternal tract with the hypopterum, which is so evident in some of the grouse. The rectrices are remarkably constant in number, usually only 12 and never more than 14, nor are there more than 16 secondaries. In addition to the 4 feathers of the alula, there is usually present on the thumb 
a well-developed claw, which is quite characteristic of the quails, being found in all except Oyrtonyx, and reachirg its maximum in Oreortyx. It consists of a horny sheath covering the terminal phalanx of the pol-

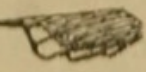

$a$
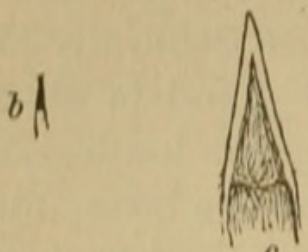

Fra, 1,-CLAW ON THE тнимв, Овеовтух, $a$, THUMB, NATURAL SIZE; $b$, CLAW, NATURAL BIZE; $c$, CLAW, X4. lex, which is here free from the skin. Its structure will be clearly seen from the accompanying figures. The ten primaries usually rank about as follows, counting from the wrist joint out: 7 , $6,5,8,4,9,3,10,2,1$. That is, the fifth is usually longer than the eighth, and always longer than the ninth; and the fourth is much longer than the tenth, which is shorter than the third. The feet are never feathered at all, the cervical tract always ending at the tibio-tarsal joint. There are no peculiar tracts or apteria on the sides of the neck, and the head is fully feathered, without apteria over the eyes, and often with special feathers or a crest on the crown, but the nasal fossie are bare. Of the seven quails indigenous to North America I have examined all except the masked bobwhite. They fall very naturally into five genera, characterized thus:

\section{ANALYTICAL KEY TO GENERA.}

I. Rectrices 12. Secondaries 14. Head without any crest or peculiar feathers.

Colinus.

II. Rectrices 12. Secondaries 15. Head with erect crest of six, rarely seven feathers, forming a clearly defined tract in the pteryla of the crown ......... Lophorty.

III. Rectrices 14. Secondaries 14. Head loosely crested with more than ten long feathers which are not erect and form only an indefinite tract in the pteryla

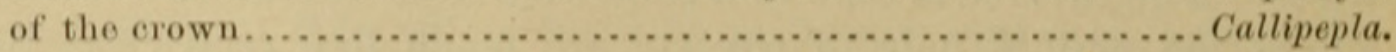

IV. Rectrices 12. Secondaries 16. Head with a crest of two very long feathers, extending backward and not erect, forming a characteristio tract in the pteryla

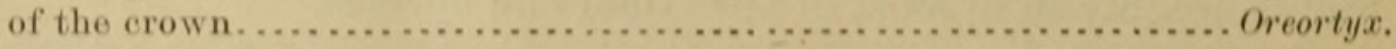

V. Rectrices 12. + Secondaries 14. Head with most of the occipital feathers long and soft, forming a very heavy, short, but not erect erest, not forming a distinct tract in the pteryla of the crown. Cyrtonyx.

\section{COLINUS.}

(Plate XLVII.)

Material examined: Five specimens of $C$. virginianus. The large series of skins in the U. S. National Museum of C. virginianus, C. v. texanus, C. v. floridanus, C. graysoni, and C. ridgwayi were examined in respect to the number of rectrices and the presence of a claw on the thumb.

The pterylosis of this genus is typical of the quails and shows very plainly the characteristics already mentioned. Although there is no dorsal apterium, the feathers between the shoulders are fewer and much weaker than farther back or on the neck. There are 14 (sometimes 15) secondaries. The claw on the thumb is well developed. The rectrices are always 12 . Nitzsch credits the bobwhite with only 12 or 13 secondaries, but he probably did not have fresh material and it would be almost impossible to determine the number correctly from a skin. 


\section{LOPHORTYX.}

Material examined: Five specimens of $L$. californica and three of $L$. gambeli, kindly furnished me by Mr. Frederic Hall Fowler, then of Fort Bowie, Arizona, Mr. F. Stephens, Witch Creek, California, and Mr. F. A. Ward of Rochester, New York. The large series of skins in the U. S. National Museum, consisting of fifteen skins of L. gambeli, twenty-five of L. californica, and L. $c$. vallicola, and eight of $L$. elegans bensoni, were examined in respect to the number of rectrices and the claw on the thumb and the number of feathers in the crest.

The pterylosis of this genus is in general like that of Colinus, but in some specimens there is a trace of a small dorsal apterium, and the ventral tract is somewhat wider before it forks. There is, furthermore, a distinct tract on the crown made by the large feathers of the crest, as shown in fig. 2. This tract consists of six or seven feathers and is somewhat triangular in outline. The number of feathers seems to be very constant, without regard to age or sex; L. gambeli and L. californica always have six, and L.elegans seven. There are 15 (sometimes 16) secondaries. The claw on the thumb is well developed. The number of rectrices is constantly 12 , but in two skins of $L$. californica (both females) there were only 10 , and in two other females of the same

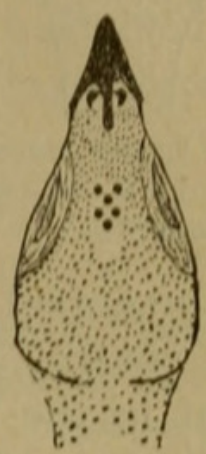

Fig. 2.- РтекyLosis OF THE CROWN. LopHonту. species there were 14. It would be interesting to have a series of several hundred birds examined, and find out how rare these exceptions are.

\section{CALLIPEPLA.}

Material examined: Two specimens of C. squamata, sent me by Mr. F. H. Fowler, Fort Bowie, Arizona. Twelve skins of C. squamata and seven of C. 8. castaneogastris, in the U. S. National Museum, were examined in respect to crest, rectrices and claw on thumb.

General pterylosis similar to Colinus, but the feather-pits between the eyes are somewhat larger and more numerous than elsewhere on the crown. There is, however, no special tract made by the feathers of the crest, which are always more numerous and softer than in the crest of Lophortyx. There are only 14 secondaries. The claw on the thumb is present. There are always 14 rectrices.

\section{OREORTYX.}

Material examined: Two specimens of $O$. pictus, for which I am indebted to $\mathrm{Mr}$. C. W. Swallow, Willsburg, Oregon. The series of skins in the U.S. National Museum were examined in respect to the feathers in the crest, the rectrices, and the claw on thumb.

General pterylosis similar to Colinus, but showing a little tendency toward that of the grouse. The feathers of the posterior part of the upper cervical tract are large and few, so that the continuity between the dorsal and cervical tracts is somewhat interrupted. On the crown 
between the eyes is a narrow apterium, in which are placed the two feathers of the crest, one behind the other, as shown in fig. 3 . The arrangement of the primaries differs from the other quail and approaches Bonasa; the fifth primary is much longer than the $n$ inth, which is a little longer than the fourth, while the tenth is much shorter

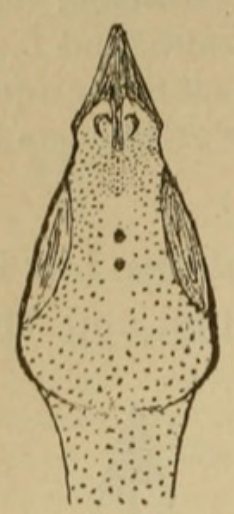

Fig. 3. - Pterylosis OF THE CROWN. OREORTYX. than the latter but longer than the third. There are 16 secondaries. The claw on the thumb is very well developed. The rectrices are always 12 .

\section{CYRTONYX.}

Material examined: One specimen, a beautiful male, kindly sent me by Mr R. D. Lusk, Fort Huachuca; Arızona. A few skins in the U S. National Museum were also examined in respect to rectrices and claw on thumb. It was only after five years of effort that I succeeded in getting a specimen of this genus, which has proved much the hardest to obtain of any of our American Gallinæ. I am therefore under special obligation to Mr. Lusk.

The dorsal pterylosis is not noticeably different from Colinus, but on the ventral surface this genus resembles Nitzsch's figure of Gallus. That is, the ventral tract runs up on the breast so far as to connect with the anterior part of the sternal tract by two rows of feathers on each side. The pterylosis of the head is like that of Colinus, there being no special tract on the crown. There are 14 secondaries, of which the first is only about two-thirds the length of the second. The claw on the thumb seems to be wanting. The middle pair of the 12 short rectrices is much longer than the outer, but the entire tail is pretty well concealed by the coverts. The tuft on the oil gland is small and of few feathers.

\section{TETRAONINAE.}

The grouse of 'North America form as clearly defined a group as the quails, although they show more generic variation in the pterylosis. In spite of these variations the distribution of the tracts is very constant and may be easily recognized as distinctive. Although strictly gallinine it differs slightly from that of the quails on the one hand and the turkey on the other, but is nearer the latter. The dorsal tract is usually more or less disconnected from the upper cervical, and as the latter is generally forked the central dorsal apterium, as we may call it, appears. As a rule the lower cervical tract remains single until near the furcula, and the ventral tracts run up so far on the breast as to almost unite with the sternals at that point, so that in an adult grouse there is very little of the ventral surface, which is entirely free from contour feathers, except along the median line. The pteryla crurales, or more properly, perhaps, the pteryla pedales, vary a great deal from the half-bare shank of Bonasa to the completely feathered toes of Lagopus. There are no peculiar tracts on the crown due to crests, but there is almost always a large apterium over each eye, and on the 
sides of the neck there are usually peculiar tracts or spaces which make good generic characters. The number of rectrices is very variable, some genera having a perfectly constant number, while others are very irregular. Usually there are 16 or 18 , but often there are 20 , and sometimes 2:. In the wing the number of primaries (10) and alula feathers (4) is as in the quails, but there is no claw on the thumb. The secondaries, never less than 16 , may be as many as 21 . The proportion of the primaries differs from that of the quails, though the exact arrangement is not constant. The wing is pointed by the sixth, seventh, and eighth primaries, which are about the same length; the fifth is much shorter than the eighth and about equal to the ninth; the fourth about equals the tenth, which is generally much longer than the third. Of the 13 species of grouse native in this country I have examined 10. They fall naturally into seven genera, characterized pterylographically in the following key:

\section{ANALYTICAL KEY TO GENERA.}

I. Sides of neck without peculiar tracts or extraordinary apteria.

1. Feet feathered only to base of toes in front. Dorsal apterium small. Femoral tracts proportionately large. Secondaries usually 18. Number of rectrices

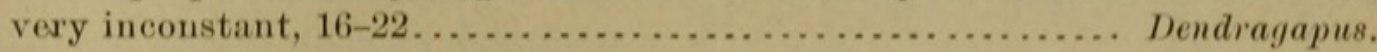

2. Feet feathered only to base of toes in front. Dorsal apterium long. Femoral tracts proportionately small. Secondaries usually 17. Number of rectrices

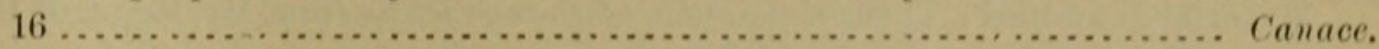

3. Feet feathered almost to claws in front. Dorsal apterium long. Femoral tracts proportionately small. Secondaries 18 or 19 . Number of rectrices

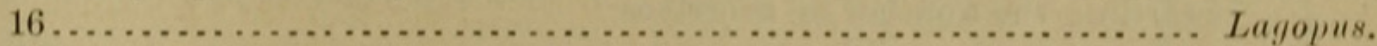

II. Sides of neck with special tracts or extraordinary apteria.

4. Feet only feathered a very little way down on the tarsus in front. Special neck tracts on the lateral branches of the lower cervical tract. Rectrices 18

Bonasa.

5. Feet feathered to base of toes. Special neck tracts on sides of upper cervical

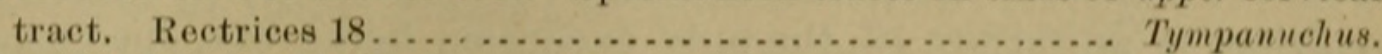

6. Feet feathered to base of toes. No special tracts on neck, but a special apte. rium on each side. Rectrices 18 , of which the middle pair are much the

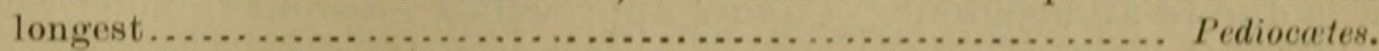

7. Feet feathered to base of toes. Lateral neck spaces almost wanting and replaced on each side by a large elliptical apterium, forming the air sac. Rectrices $16-20$.................................... Centrocercus.

\section{DENDRAGAPUS.}

\section{(Plate XLVIII.)}

Material examined: Six specimens of D. obscurus, fonr from Eadsville, Wyoming, the gift of Dr. Jesurun, and two from Prof. G. S. Thompson, Boulder, Colorado, and one of D. o. fuliginosus from British Columbia from Mr. John Fannin. In addition, fourteen skins of $\mathrm{D}$. obscurus, twenty of $\mathrm{D}$. o. fuliginosus, and nine of D. o. richardsoni, chiefly from the U. S. National Musenm, have been examined in regard to the number of rectrices.

The general pterylosis of this genus is so clearly shown in the plate that no further explanation is needed. The secondaries seem to be uni- 
formly 18. In the number of rectrices we find the most remarkable diversity, as is shown by the following table:

Number of rectrices in Dendragapus.

\begin{tabular}{|c|c|c|}
\hline D. obscurus. & D. o. fuliginosus. & D. o. richardsoni. \\
\hline $\begin{array}{l}2 \text { specimens have } 16 . \\
1 \text { specimen has } 17 . \\
14 \text { specimens have } 18 \text {. } \\
3 \text { specimens have } 20 \text {. } \\
70 \text { per cent have } 18 \text {. } \\
\text { The average number is } 18 .\end{array}$ & $\begin{array}{l}1 \text { specimen has } 14 \text {. } \\
2 \text { specimens have } 16 \text {. } \\
6 \text { specimens bave } 17 \text {. } \\
12 \text { specimens have } 18 \text {. } \\
57 \text { per cent have } 18 \text {. } \\
\text { The average number is } 17.3 \text {. }\end{array}$ & $\begin{array}{l}1 \text { specimen has } 19 \text {. } \\
6 \text { specimens have } 20 \text {. } \\
1 \text { specimen has } 21 \text {. } \\
1 \text { specimen has } 22 \text {. } \\
\text { None bave } 18 \text {. } \\
\text { The arerage number is } 20.2 \text {. }\end{array}$ \\
\hline
\end{tabular}

It is unfortunate that a larger number of specimens was not available for comparison, but it seems clear that fuliginosus and richardsoni represent opposite extremes in the variation in the number of rectrices. Not having had any specimens of richardsoni in the flesh, I can not say whether a similar extreme is shown in other characters or not. If 18 was the number of rectrices characteristic of the ancestor of the tree grouse, then fuliginosus shows a tendency to follow canace in the loss of a pair, while richardsoni has already acquired an additional pair. Further investigation into this question will doubtless prove of interest.

\section{CANACE.}

Material examined: Three specimens of C. canadensis from Mr. Egan, of Halifax, and one of C. franklini from Mr. Fanun, of Victoria, British Culumbia. Sixteen skins, chiefly from the U.S. National Museum, have been examined regarding the number of rectrices.

General pterylosis differs from that of Dendragapus in having a longer dorsal apterium, femoral tracts much smaller in proportion to the size of the bird, and the ventral tracts more distinctly separated from the sternals. The secondaries are 17 in number. The number of rectrices is uniformly 16 , the only exception being one specimen with only 14. I am inclined to think that in this case the loss of one pair was due to an accident. Canace approaches Lagopus in most respects, and appears to be a sort of connecting link between that genus and Dendragapus.

\section{LAGOPUS.}

Material examined: Four specimens of L. lagopus from Mr. Egan, Halifax, Nova Scotia, and two from Mr. William Clark, Winnipeg, Manitoba; three of $L$. rupestris from Mr. Egan, and two of L. welchii from Mr. Egan. The latter were identified for me by Dr. J. A. Allen. All of the specimens Mr. Egan sent me were collected in Newfoundland.

The dorsal apterium is longer than in Dendragapus, the femoral tract much smaller proportionately, and the ventral tracts are not so obviously connected with the sternal. The feet are feathered almost to the claws in front, but the tarsus is bare behind. The apterium over the eye was very small or wanting in welchii. No other specific differences were observed and there was little individual variation. The secondaries are 18 or 19 in number and the rectrices are 16, though the middle pair 
are not easily distinguishable from the long coverts. In general, Lagopus approaches quite closely to Canace. Nitzsch credits Lagopus with 1s rectrices, but he must have mistaken the middle pair of coverts for tail feathers. Coues considers the tail made up "normally of 14 " feathers, but adds that the middle pair of coverts are usually reckoned as rectrices. I am confident, however, that this extra pair are not coverts, but true rectrices.

$$
\text { BONASA. }
$$

Material examined: Four specimens of our eastern B. umbellus and one of B. $u$. togata, the gift of Mr William Clark, of Winnipeg, Manitoba.

In its general pterylosis this genus differs from Dendragapus in having the dorsal apterium somewhat larger, and the lower cervical tract forks very much farther up on the throat. The branches of the latter bear the "ruffs," which form a peculiar tract on each side. There is a small apterium on each side at the base of the upper mandible, in front of and below the eye. The feet are only feathered down a short distance in front. The rectrices are always 18 and the secondaries 15 or 16 , somewhat fewer than in other grouse. Nitzsch's observations agree entirely with mine.

\section{TYMPANUCHUS.}

Material examined: Two fine specimens of $T$. americanus, for which I am indebted to Mr. Carl F. Hemming, of Boone, Iowa.

The general pterylosis is almost precisely like Dendragapus, but the dorsal apterium is smaller and the

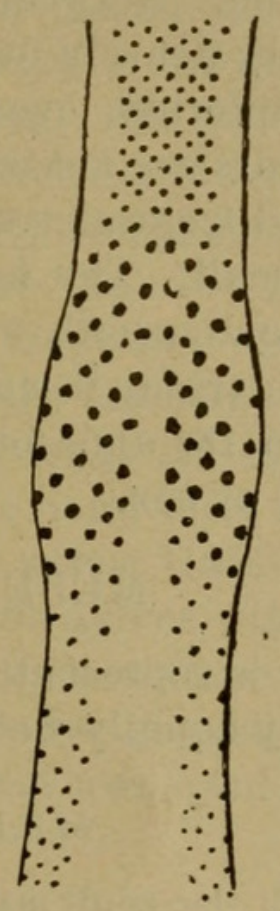

$a$

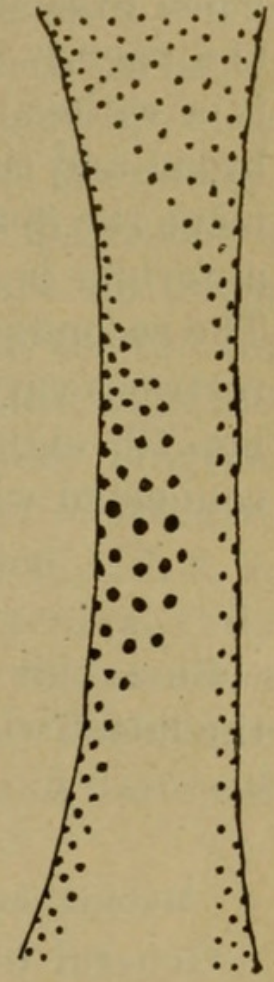

$b$

Fig. 4.-SPEcial Neck tracts of Bonasa. $a$, SeEN From Below. $b$, SeEn from the SIDE. upper cervical tract is very narrow.

The latter bears on each side a conspicuous tuft of about a dozen large feathers, which form a very evident and characteristic tract, underneath which is a large and peculiar apterium. The apteria over the eyes are small. The feet are feathered to the base of the toes. The hook-sliaped tract on the side is quite conspicuous. The tail consists of 18 feathers and there are 18 secondaries, as recorded by Nitzsch for T. cupido.

\section{PEDIOC $\nRightarrow$ TES}

Material examined: Four specimens of $P$. phasianellus columbianus.

General pterylosis seems to approach that of Bonasa, but there are no special tracts on the sides of the neck and the feet are feathered clear down on the toes in front. The tracts on the sides under the 
wings are conspicuous. The apteria on back and belly are inconspicuous, but those over the eyes are evident. There are 18 secondaries and 18 rectrices.

\section{CENTROCERCUS.}

Material examined: One full-plumaged male, two females, and three young birds of $\dot{C}$. urophasianus, for which I am very deeply indebted to Dr. Mortimer Jesurun, of Douglas, Wyoming. Seven skins in the U.S. National Museum were also examined regarding the number of rectrices.

The pterylosis is quite distinctive, though the dorsal and ventral tracts are much like Dendragapus. There are no lateral neck spaces, but the whole neck is thickly feathered, and the sternal, cervical, and humeral tracts are all united on the shoulder. On each side of the neck is a large sharply defined apterium of orange colored skin, some. what oval in outline. Between and beneath these the skin is thick and spongy and very densely feathered, especially in the male. There is a rather large apterium over each eye. All of the tracts are very broad and their limits are not easily determined, so that in some specimens the dorsal and femoral tracts seem almost united and the dorsal apterium is very small. The feet are feathered to the toes in front. The secondaries are unusually numerous, $21 \mathrm{in}$ all the specimens. The rectrices vary considerably in number; of 13 individuals examined one has 16 , eight have 18 , anả four have 20 , and this diversity is not connected with age or sex.

\section{MELEAGRIDID $Æ$.}

Since this family is represented by only a single genus, comments on the latter will apply equally well to the former.

\section{MELEAGRIS.}

Material examined: One adult male and two females of $M$. gallopara.

General pterylosis has been well figured by Nitzsch. It resembles that of Dendragapus, but there is no separation of the upper cervical frow the dorsal tract, and the spinal apterium is long and narrow; the ventral tract is not united at the end of the breastbone, but remains divided almost to the anus; and lastly, the head and upper part of the neck being bare, the two branches of the lower cervical tract are nowhere united into one. Half-down is abundant, obscuring the boundaries of the tracts. The wing is pointed by the sixth and fifth primaries, the seventh about as long, the fourth a little shorter and nearly equaled by the eighth and third, while the ninth and second are somewhat shorter still. There are 18 rectrices and only 18 secondaries, but the alula contains 5 feathers. The feet are feathered only to the tarsal joint. In the male, a special pteryla is formed on the lower part of the throat by a peculiar tuft of long bristles, but there is nothing corresponding to it in the females. My observations accord with those of Nitzsch, except that $I$ found 5 feathers in the alula instead of 4 , and the femoral tracts are proportionately broader than in his figure. 


\section{CRACIDA.}

This family is also represented in the United States by a single genus.

\section{ORTALIS.}

(Plate XLIX.)

Material examined: Five specimens from Brownsville, Texas, kindly furnished by Mr. Frank B. Armstrong.

The general pterylosis differs considerably from that of the grouse or quail, and these peculiarities will be seen on examination of the plate. There are large apteria on the cheeks and chin, and the lateral neck spaces are very short. The sternals are long and narrow, while the ventral tract forms a long, slender, hollow triangle, with the apex forward and the base in front of the anus. The femoral tracts are entirely fused with the posterior part of the dorsal, and the latter is Lot separated from the upper cervical. On the wing there are only two rows of major secondary coverts, but the other coverts are numerous and rather irregularly scattered. The alula consists of five feathers and there is a prominent claw on the thumb. There are no down feathers, the aftershafts are small, the filoplumes short, and the tuft on the oil gland is very small. The legs are feathered down just over the tarsal joint in front. Rectrices 12, long, the middle pair longest. Secondaries 15. Primaries 10, but the outer ones are very short, giv. ing a formula very different from our other Gallinæ, 23456, 1, 7, 8, 9, 10. In most of these particulars Ortalis agrees with the genera, Crax and Penelope as described by Nitzsch, but there seem to be some important differences, particularly in the ventral tract. The lower part of the main shaft of the contonr feathers is enlarged and flattened as Nitzsch describes in Crax.

\section{CONCLUSIONS.}

In the light of the foregoing facts it may be possible for us to draw -some conclusions on the relationship of the genera, but it must be confessed we shall hardly be justified in going much beyond that. The group is remarkably homogeneons, at least as far as its. North American representatives are concerned, but it is probable that a careful examination of the Eastern Phasianidx, the South American Cracidre, and the Australasian Megapodida will bring to light greater diversity. Our single representative of the Cracida is obvionsly further from the gallinine type than any of our other species, and without further study of the family it is impossible to draw any conclusions in regard to the relationship of the guans to the other Gallina. With the Alecteropodes, however, the case is different, and the relationship of the different genera is at least suggested by these investigations. The position to be given Meleagris is a question on which the work so far done throws very little light, but its relation is probably nearest to the Phasianidse.

The differences between the grouse aud the quail are in part at least 
due to the greater size of the former, and we may assume that the latter represent more nearly the primitive condition. This assumption is based on the greater simplicity of the dorsal tract and the cervical tracts in the quails and the small number of rectrices. At the same time it must be remembered that it is a pure assumption adopted only for convenience in pointing out the relation of the genera to each other. The common bob white and its allies will serve, then, as a starting point from which to develop the other genera. Lophortyx is nearest to Colinus, having the same number of rectrices and resembling that genus closely in other ways. But some of the feathers of the crown form a distinct crest tract. From Lophortyx may have been derived, on the one hand, by increased size and greater specialization of the crest, the genus Oreortyx; and on the other hand, by reverse changes in the crest and increase in the number of rectrices, the genus Callipepla. The degeneration of the crest has gone further in Oyrtonyx than in Callipepla, but the 12 rectrices have been retained, though they have greatly degenerated in size and importance. This arrangement of the genera may be seen at a glance from the accompanying diagram:

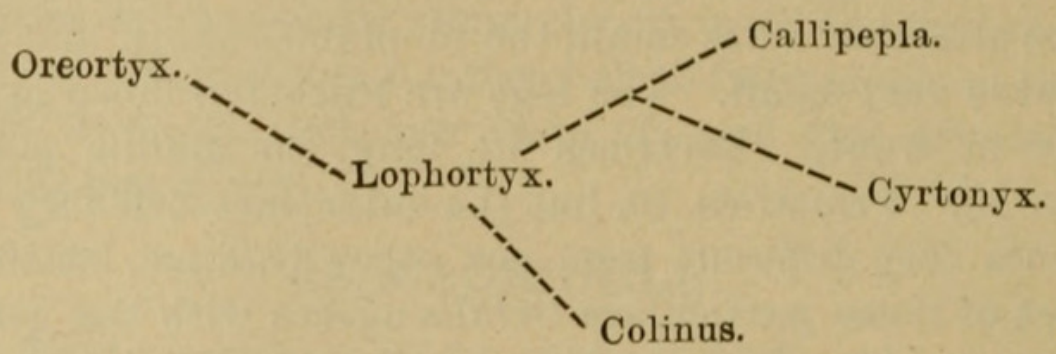

Which genus of grouse to use as a starting point is not so easy to decide, but for convenience we will take Canace. It must not be supposed, however, that this is meant to imply that that genus is nearest to the quails. But it has the smallest number of rectrices and the simplest pterylosis, and it is easy to show its connection with most of the other genera. Dendragapus has developed from Canace by increase of size, accompanied by greater development of the femoral tracts, a marked increase in the number of rectrices, and some changes in the dorsal tract. Lagopus has been modified from Canace only in the greater amount of feathering on the feet and the greater development of upper tail coverts. Tympanuchus, Pediocates, and Bonasa, form still another branch, of which the first is perhaps nearest the ancestral form, and Bonasa the most modified. All three of these genera have an increased number of rectrices and modified cervical tracts or apteria. In Bonasa there has been a marked decrease in the amount of feathering on the feet, and the special pterylæ on the branches of the lower cervical tract are very noticeable. The position of Centrocercus is not easy to determine, as it shows greater specialization than any other genus. This is indicated by the changes in the arrangement of the cervical tracts, in the greater size of the dorsal and femoral tracts, and in the increased number of rectrices. Whether it is the descend- 


\section{$2 \mathrm{BHL}$ Biodiversity Heritage Library}

Clark, Hubert Lyman. 1899. "The feather-tracts of North American grouse and quail." Proceedings of the United States National Museum 21(1166), 641-653. https://doi.org/10.5479/si.00963801.21-1166.641.

View This Item Online: https://www.biodiversitylibrary.org/item/53529

DOI: https://doi.org/10.5479/si.00963801.21-1166.641

Permalink: https://www.biodiversitylibrary.org/partpdf/52616

\section{Holding Institution}

Smithsonian Libraries

\section{Sponsored by}

Smithsonian

\section{Copyright \& Reuse}

Copyright Status: Public domain. The BHL considers that this work is no longer under copyright protection.

This document was created from content at the Biodiversity Heritage Library, the world's largest open access digital library for biodiversity literature and archives. Visit BHL at https://www.biodiversitylibrary.org. 